\title{
Os nomes da Revolução: lideranças populares na Insurreição Praieira, Recife, 1848-1849
}

Marcus J. M. de Carvalho Universidade Federal de Pernambuco

\section{RESUMO}

Este artigo retoma o problema da participação de agentes advindos das camadas subalternas na Insurreição Praieira (1848-49), e nas manifestações de rua que a precedem, buscando dimensionar esta participação e investigar as possíveis motivações dos participantes. Quinze funcionários dos baixos e médios escalões do aparato estatal e vinte e dois artesãos foram denunciados no inquérito contra a rebelião. Entre eles havia sedutores de povos que comandavam reuniões em suas lojas. Alguns mais ousados chegaram a atirar nas tropas imperiais no combate do Recife. A Praieira serve de prisma para se estudar os limites da obediência da clientela às malhas patronais e a formação de lideranças populares capazes de intermediar as relações entre a haute politique partidária e os interesses imediatos dos trabalhadores livres pobres urbanos.

Palavras-chave: Insurreição Praieira; trabalhadores livres; lideranças populares.

\section{ABSTRACT}

This article deals on the problems related to the involvement of subordinate sectors in the Praiera Insurrection (1848-49) and the street demonstrations that precede. It tries to appraise this participation and investigate the probable motivations. Fifteen low and medium rank workers of the state apparatus and twenty-two craft workers were charged in the inquest. Among them, there were "persuasive elements" that lead meetings in their shops. The boldest ones even shot at the imperial troops in the Recife combat. The Praieira serves as the angle to study the client's compliance to the ruling network and the forming of grassroot leaderships able to mediate the relationship between the haute politique and the immediate interests of free deprived urban workers.

Keywords: Praiera Insurrection; free workers; grassroots leadership. 
Uma das maiores preocupações da História Social tem sido interpretar a participação dos grupos subalternos nas grandes convulsões sociais, aqueles momentos de violência politicamente direcionada dos quais as sociedades mais cedo ou mais tarde dificilmente escapam. É questão recorrente na historiografia sobre o século XIX avaliar até que ponto aquela massa complexa que as autoridades chamavam com desdém de escória, ralé, populaça, turba - a multidão, como diriam Rudé e Thompson — agia com independência nessas ocasiões, seguindo motivações diferentes, quando não inteiramente opostas às intenções das facções das elites em disputa pelo poder. Pairam sempre algumas perguntas no ar: Será que os participantes das camadas subalternas formavam apenas uma massa de manobra sem representação política própria, atendendo aos interesses das camadas superiores? Ou, ao contrário, agiam com autonomia, buscando satisfazer anseios específicos do grupo? Até onde os contextos situacionais em que estavam imersos permitiam-lhes uma visão dos acontecimentos clara o suficiente para guiar seus atos além do roteiro estabelecido pelo patronato político rural e urbano?

Lamentavelmente não é fácil responder a questões desse tipo. Mas observando um caso concreto, a Insurreição Praieira, é possível avançar algumas idéias sobre as complexas motivações que podiam levar agentes sociais distintos a agir em comum, dentro de uma sociedade escravista, mesmo tendo interesses nem sempre coincidentes. Para Joaquim Nabuco, os praieiros representavam o povo pernambucano todo. Em Um Estadista do Império é indisfarçável seu fascínio, quase atônito, com o entusiasmo do povo do Recife com a principal bandeira dos praieiros, a chamada nacionalização do comércio a retalho. O liberal radical Borges da Fonseca também ressaltou o apoio popular à Praieira, uma opinião compartilhada pelo principal líder do Partido Conservador depois da insurreição, o barão de Camaragibe, para quem 9/10 da população pernambucana estava com os praieiros. Também pensavam de forma semelhante os cronistas coevos Antônio Pedro de Figueredo e Nascimento Feitosa. Ambos eram da oposição durante o governo praieiro, mas passaram a defendê-lo depois da derrota da rebelião, pregando a conciliação entre os partidos ${ }^{1}$. Tomando cuidado para não assumir como verdade absoluta os excessos retóricos dos participantes, este artigo busca identificar as lideranças advindas das camadas subalternas, escondidas atrás dos grandes líderes partidários, perscrutando assim as motivações que levaram uma parte da população livre urbana a participar da insurreição e da mobilização dos anos anteriores. Na primeira parte, serão discutidas as representações deixadas por alguns contemporâneos que vivenciaram aqueles episódios. Para o liberal radical Borges da Fonseca, o que aconteceu em Pernambuco foi a revolusão (sic) de novembro. A segunda parte busca identificar e dimensionar esse tal povo envolvido na Praieira. As camadas subalternas participavam da cons- 
trução das malhas patronais, surgindo no processo algumas lideranças advindas do artesanato urbano. O resultado é que a obediência ao patronato político tinha limites. Os grupos subalternos tinham interesses a defender. A terceira parte investiga as motivações da parcela da população livre pobre que se engajou no movimento praieiro. Como estudo de caso, a Praieira serve de prisma para se observar o funcionamento do clientelismo urbano e as condutas políticas dos grupos subalternos que não ficavam necessariamente indiferentes às disputas político-partidárias no Brasil imperial.

\section{OS NOMES E AS FACES DA INSURREIÇÃo PRAIEIRA}

A rica literatura sobre a Praieira ensina que sua história começa no início da década de 1840, quando apareceu em Pernambuco uma dissidência do Partido Liberal, mais conhecida pelo apelido de "Partido Praieiro". A razão para esta divisão é que os conservadores eram liderados na província pelo barão da Boa Vista e por dois dos irmãos Cavalcanti. Acontece que o terceiro irmão, Holanda Cavalcanti, filiou-se ao Partido Liberal, tornando-se um ativo tribuno na Assembléia Geral. Junto com seus primos da Paraíba, praticamente formavam uma bancada própria, que contava ainda com o apoio de Araújo Lima, futuro marquês de Olinda. Posteriormente, os três irmãos iriam se tornar senadores, caso único na história do Brasil. O resultado é que, qualquer que fosse a conjuntura, desde o regresso de 1837 os Cavalcanti estavam representados direta ou indiretamente nos gabinetes ministeriais.

E assim aconteceu, quando Pedro II chamou o Partido Liberal para compor o ministério, inaugurando o qüinqüênio liberal (1844-1848). O problema para os Cavalcanti, todavia, é que na Corte os deputados por Pernambuco vinculados ao Partido Praieiro haviam se aliado a Aureliano, o visconde de Sepetiba, que segundo Nabuco, tinha uma enorme influência pessoal sobre Pedro II. Liderada por Nunes Machado, a barulhenta bancada praieira na Corte defendia ativamente seus interesses locais. Assim, mesmo estando nos gabinetes liberais até 1847, Holanda disputava com eles a nomeação dos presidentes de Pernambuco. Em 1845, o pêndulo finalmente caiu para o lado dos praieiros, abrindo a oportunidade para que governassem a província.

O novo presidente, Chichorro da Gama, foi recebido entusiasticamente pelos praieiros. Tinha fama de ser um homem enérgico, pois quando ainda era um simples juiz na Corte, assinara o mandado de prisão de José Bonifácio. Chichorro da Gama administraria a província até abril de 1848. Durante seu mandato, candidatou-se duas vezes ao Senado Imperial por Pernambuco. Embora tenha ganho as eleições - , como seria de esperar, já que a situação era sempre vitoriosa —, ambos os pleitos foram anulados pelo Senado Impe- 
rial, onde os Cavalcanti e seus aliados eram mais poderosos. As alegações para a nulidade eram muitas: irregularidades cometidas pelas mesas de qualificação, constrangimento ilegal dos votantes e eleitores, roubo de urnas, uso de violência nos locais de votação, etc. Durante o qüinqüênio liberal, todas as eleições foram acirradas em Pernambuco, inclusive as que renovavam os mandatos nas Câmaras e na Assembléia Provincial. No Recife, houve pelo menos sete manifestações de rua, nas quais a população urbana agrediu portugueses e estrangeiros em geral, saqueou lojas e exigiu a nacionalização do comércio a retalho. As facções engajadas nas disputas eleitorais acusavam seus adversários na imprensa panfletária de serem os responsáveis por esses mata-marinheiros ocorridos na cidade.

Ao assumir o poder, o governo praieiro começou a substituir os delegados e subdelegados de polícia na província, o que aumentaria imensamente o poder das suas bases locais. Em torno de 600 autoridades foram demitidas e, obviamente, substituídas por aliados dos praieiros. Houve reação e atritos armados em várias localidades, principalmente durante as eleições, atestando a insatisfação de muitos proprietários com a chamada gangorra da política imperial. Com a queda dos liberais na Corte em 1848, a gangorra cairia do outro lado, recomeçando o festival de demissões. Um grupo de mais de 40 proprietários rurais ligados aos praieiros, todavia, recusou-se a entregar os cargos na polícia e a devolver as armas em seu poder. A Insurreição Praieira começou quando uma tropa foi tentar desarmar o coronel praieiro Manoel Pereira de Moraes, senhor do engenho Inhamam, em novembro de 1848. A raiz da Praieira foi esta disputa pelo poder local, principalmente pelos cargos na Polícia Civil, e secundariamente na Assembléia Provincial, nas Câmaras, na Justiça de Paz e Guarda Nacional'2. Apesar da historiografia concordar em muita coisa, o dissenso todavia é grande quando se trata de interpretar as articulações tecidas entre os grupos envolvidos no conflito. Essas articulações aparecem condensadas nas representações que os contemporâneos construíram sobre o momento em que viviam.

Os nomes dados às coisas são sempre reveladores, pois servem para exprimir as qualidades inerentes ao objeto, que quanto mais complexo mais camadas de significado possui. Abalados pelas repercussões dos acontecimentos que os cercavam, reverberando em seus cotidianos, os contemporâneos referiam-se à Insurreição Praieira como insurreição, revolta, guerra do Moraes, revolução e Cabanada. Estes nomes têm uma história, pois cada um deles sintetiza um conjunto de significados específicos que correspondem às percepções de observadores distintos que chamaram o que viam de uma maneira e não de outra. Essas representações podem ser interpretadas, permitindo uma recomposição mais precisa de algumas das faces do universo do 1848 pernambucano. 
O chefe de polícia que esmagou a rebelião, um oficial do Exército que participou da repressão, e um deputado praieiro escreveram livros sobre aqueles eventos. Logo nos títulos chamam a Praieira de rebelião ou revolta, termos que aqui neste artigo e no nosso cotidiano são sinônimos de insurreição. Mas não era assim no século passado ${ }^{3}$. José Honório Rodrigues observou que rebelião ou revolta referia-se a movimentos armados que envolviam grupos sociais qualificados, mas que não tinham base em princípios políticos ou objetivos reformistas ${ }^{4}$. Apesar da retórica e do antagonismo entre o deputado praieiro e as autoridades que contribuíram para a repressão ao movimento, os três autores concordam que o conflito intra-elite foi o cerne da Praieira.

O primeiro dos três livros a ser escrito foi a apaixonada defesa feita pelo deputado praieiro Urbano Sabino Pessoa de Mello. Para ele, os participantes eram cidadãos respeitáveis que lutaram para salvar suas vidas e propriedades contra seus inimigos vinculados à oligarquia Cavalcanti-Rego Barros, que ainda durante o governo praieiro em Pernambuco (1845-1848) tentaram dar um golpe de Estado na província. Os rebeldes, portanto, estariam defendendo princípios legais e constitucionais que haviam sido transgredidos.

A resposta a esses argumentos veio no livro publicado por Figueira de Mello, o chefe de polícia que esmagou a revolta. Para ele, os rebeldes aliaramse com os grupos subalternos liderados por Borges da Fonseca. A rebelião teria representado um perigo real à ordem. Mas as motivações dos praieiros teriam sido fúteis, faltando ao movimento uma ideologia social e política definida. Para ele, o que houve em 1848-49 foi um grande desperdício de vidas e recursos que em nada beneficiou os proprietários e homens de bem da província.

Anos depois da rebelião, um militar que em sua juventude havia participado da repressão escreveu um conjunto de crônicas sobre o episódio, posteriormente publicadas em livro. O general Mello Rego negou qualquer ligação da Praieira com o advento de idéias republicanas, argumentando que não havia nenhum princípio político ou programa, além da defesa de uma facção das elites. Para ele (p.10), os membros das principais famílias pernambucanas por igual se contavam (...) tanto no partido praieiro como no do governo...

Vê-se, portanto, que embora assumindo posições distintas, esses cronistas-participantes dos eventos de 1848 enfatizaram o papel das classes proprietárias no movimento. Ao negar a existência de qualquer programa de reformas mais amplas na Praieira e considerar fúteis as motivações dos proprietários rurais envolvidos, o chefe de polícia Figueira de Mello terminou reconhecendo o caráter elitista da revolta. Elitismo confirmado pelo deputado praieiro Urbano Sabino, que enfatizou que a intenção primordial dos rebeldes era defender suas propriedades. Para ambos, a revolta-rebelião foi o principal as- 
pecto da Praieira. O general Mello Rego sintetizou este discurso ao afirmar que as elites se dividiram por igual nos anos quarenta em Pernambuco.

Do lado dos praieiros, o manifesto dos seus deputados à Assembléia Geral expressa bem as reivindicações elitistas dos proprietários rebeldes: a federação e uma nova Assembléia Constituinte são os limites do discurso normativista. Ao povo, uma única concessão: a nacionalização do comércio a retalho. Analisando cuidadosamente os programas partidários no império, Jeffrey Mosher demonstrou que esta reivindicação distinguia claramente o programa do Partido Liberal daquele do Partido Conservador ${ }^{5}$. Em linhas gerais, é esta a face revolta-rebelião da Praieira: um atrito armado resultante da radicalização de uma disputa intra-elite pelo poder político local e cargos correspondentes.

Um outro nome dado à Praieira foi Guerra do Moraes. Assim, teria ficado conhecido o 1848 pernambucano na tradição oral dos habitantes da Zona da Mata seca, ao norte do Recife, onde o principal líder rebelde foi Manoel Pereira de Moraes, senhor de dois engenhos, que antes se envolvera na Confederação do Equador. A Guerra do Moraes iniciou-se antes mesmo da revolta-rebelião do deputado e do chefe de polícia. Quando o principal líder do Partido Praieiro na Corte - o deputado Nunes Machado - chegou ao Reci$\mathrm{fe}$, já haviam iniciado os combates entre as autoridades provinciais e o coronel Moraes e outros senhores-de-engenho vinculados ao Partido Praieiro, que se recusaram a devolver as armas do Estado e entregar os postos na Polícia Civil, dos quais haviam sido destituídos após a queda dos praieiros em abril de 1848. O primeiro a negar-se a entregar seu cargo foi o deputado à Assembléia Geral Antonio Affonso Ferreira, chefe de polícia da província durante o governo praieiro. Os senhores de engenho praieiros já estavam de armas na mão quando receberam a adesão dos demais deputados do partido que voltavam do Rio de Janeiro 6 .

A Guerra do Moraes foi certamente o tipo de conflito travado pela maior parte da população rural pernambucana envolvida na luta. O seu cerne era a disputa dos senhores-de-engenho pelos cargos na Polícia Civil e Justiça de $\mathrm{Paz}$, que davam uma roupagem institucional ao poder político local. Os soldados dessa guerra eram os dependentes dos potentados rurais. Como era de se esperar, em muitos casos faltou a esses soldados algum incentivo maior para a luta, resultando freqüentemente em deserções.

Para os senhores-de-engenho que arriscaram seus bens e vidas na Guerra do Moraes a anistia veio com bastante celeridade. A maior parte dos senhores-de-engenho pronunciados apenas voltou para tomar conta dos seus negócios, tentando recompor seus prejuízos já que a rebelião aconteceu no quadro da safra de cana-de-açúcar (outubro a março). Apenas Moraes, ao norte do Recife, e alguns outros plantadores na Zona da Mata úmida, ao sul 
do Recife, continuaram lutando até a derrota final da revolta. A população rural, contudo, foi quem mais sofreu com a Guerra do Moraes. As principais vítimas dos combates foram os moradores dos engenhos e não os seus patrões. Recrutamento e castigos corporais foram a punição dos participantes anônimos que sobreviveram à Praieira.

A Guerra do Moraes não foi a única face da Praieira no campo. Depois de pacificada a Zona da Mata seca, ao norte do Recife, e fracassada a tomada da capital em fevereiro de 1849, a luta não parou. Uma guerrilha continuou por mais dois anos na fronteira entre os engenhos de cana e as matas de Água Preta, na Zona da Mata úmida, já próximo à divisa com a província de Alagoas. Comandou esta guerrilha o tenente de artilharia Pedro Ivo, imortalizado por Castro Alves. Entre 1849 e 1850, as autoridades pernambucanas referiam-se a aqueles acontecimentos como Nova Cabanada. Durante a Cabanada (1832-1835), os cabanos se constituíram na maior ameaça à ordem provincial desde o Quilombo dos Palmares. Segundo Eisenberg, o conflito causou uma queda de $25 \%$ na produção açucareira pernambucana ${ }^{7}$. A Cabanada havia sido uma insurreição. De acordo com o capítulo IV do Código Penal de 1830 , este termo era reservado para movimentos de rebeldia envolvendo vinte ou mais cativos. Para José Honório Rodrigues (p.104), nas práticas discursivas do século XIX, insurreição era um termo reservado para denominar os movimentos de profunda conotação social. Foi este o caso da Cabanada, uma insurreição que juntou índios, quilombolas e outros destituídos na luta pela posse da terra e pela manutenção de direitos tradicionais, ameaçados pelas autoridades locais apoiadas por tropas do exército imperial. Entre 1849 e 1850, Pedro Ivo mobilizou gente de origens sociais distintas, inclusive alguns veteranos da Cabanada, como Caetano Alves ${ }^{8}$. Ante o perigo de que os cabanos despertassem novamente, é natural que tenha sido maior a brutalidade da repressão senhorial. A Nova Cabanada foi esmagada a ferro e fogo. A gente da mata envolvida, recrutada em massa.

O movimento armado de 1848-49 recebeu ainda um quarto nome, dado pelo liberal radical Borges da Fonseca. Ele não lutou pela Guerra do Moraes dos senhores-de-engenho, muito menos pela Rebelião Praieira dos deputados, mas sim pelo que viria a chamar posteriormente de Revolusão (sic) de Novembro. Em suas palavras: Estava aberta a luta entre o poder corruptor do Brasil e o povo.

Enquanto os praieiros estiveram no poder (de junho de 1845 a abril de 1848), Borges da Fonseca foi um tenaz adversário, acusando-os de servilidade à Coroa, denunciando tudo o que considerava incorreto ou desonesto. A imprensa praieira respondia chamando-o de anarquista, sans-culotte e republicano. Bem, coerência não era o forte de Borges, que costumava elogiar o barão da Boa Vista, figura de proa do partido conservador, e mudava de opi- 
nião com uma facilidade que só as pessoas que nada devem realmente podem ter. Ele criticava inclusive os excessos do antilusitanismo, asseverando que os franceses e ingleses eram adversários até mais perigosos para o Brasil. Como eram os praieiros que detinham o poder, foi processado e preso de agosto de 1847 a abril de $1848^{10}$. Borges da Fonseca mereceu ser conhecido como o repúblico, ao editar sonetos como: República erige o Novo Mundo/ República fará nossa Ventura/ República não quer Pedro II ${ }^{11}$.

Sendo um homem do seu tempo, não estava imune às concepções racistas da época, mas no começo de sua longa carreira já era um simpatizante da emancipação gradual dos escravos. Militou na sociedade secreta A Popular, que favorecia a emancipação gradual, e na década de 1860 flertaria com o nascente abolicionismo ${ }^{12}$. Borges também deixou explícitas suas posições como advogado. Em 1846 ingressou com um habeas corpus pedindo a soltura do negro livre Agostinho José Pereira, chamado Divino Mestre por seus seguidores. Dizendo-se contrário ao catolicismo oficial, Agostinho pregava no Recife durante o governo praieiro, alfabetizando seus discípulos também negros, utilizando uma bíblia na qual estavam grifadas as passagens que falavam de liberdade. Com sua mulher foi apreendido um verso, o $A B C$, que falava do Haiti. O chefe de polícia da província assustou-se, temendo que a seita fosse um disfarce para algum levante negro. Borges defendeu o Divino Mestre e seus seguidores no Tribunal da Relação. Podia-se gabar n'O Tribuno, lembrando aos homens de cor que era ele quem lhes informava seus Direitos ${ }^{13}$.

Sua popularidade entre os artistas mecânicos da província era reconhecida até por seus adversários. Era capaz de angariar votos no Recife e em algumas povoações do interior, principalmente Nazaré, onde morou e publicou o jornal O Nazareno. A imprensa considerava-o líder dos cinco mil, a quem eram atribuídas as agitações populares em favor da nacionalização do comércio a retalho. Esta reivindicação era o seu ponto comum com os praieiros. A população urbana estava particularmente vulnerável ao discurso nativista durante o governo praieiro, não apenas porque a disputa político partidária havia se acirrado, mas também porque aumentara o desemprego devido à paralização das reformas iniciadas no governo anterior, do barão da Boa Vista. De fato, entre 1837 e 1844 foram abertas novas ruas, construídos prédios públicos e instalado um novo sistema de abastecimento de água. Para Borges da Fonseca, o governo do barão, mesmo conservador, havia melhorado o aspecto geral da cidade e dado emprego à população urbana. $\mathrm{O}$ cônsul americano no Recife, em 1845, observou que a interrupção das obras públicas durante o governo praieiro jogou muita gente nas ruas. ${ }^{14}$ Gente que ouvia Borges da Fonseca.

Apesar de sua tenaz oposição ao governo praieiro, que o jogou na cadeia sem nenhuma regalia, Borges da Fonseca aderiu à rebelião quando começou a luta armada. Acreditava em mudanças e era capaz de arrebatar a multidão. 
Amigo pessoal do coronel Moraes e homem de fibra, ascendeu rapidamente na hierarquia rebelde. É de sua autoria o manifesto mais radical da revolta, o qual, paradoxalmente, foi assinado por senhores-de-engenho, à frente o próprio Moraes, Henrique Pereira de Lucena (pai do barão de Lucena, futuro presidente da província) e outros. Ao chegarem no Recife, os deputados praieiros recusaram-se a apoiar o manifesto de Borges. Mas precisando do apoio das tropas mobilizadas por ele, terminaram tendo que aceitá-lo como membro do Diretório rebelde. De acordo com o chefe de polícia da província que derrotou a Praieira, depois da morte de Nunes Machado, Borges da Fonseca assumiu o comando do 1848 pernambucano ${ }^{15}$.

Para ele, os rebeldes eram uma frente. Percebia, portanto, o leque de interesses envolvidos no conflito. Não obstante, considerava que a força motora do movimento era o povo. As demandas da Revolução de Novembro continham nuanças francesas, como se dizia na época, indo muito além do constitucionalismo defendido pela maioria do Partido Liberal, inclusive pela bancada praieira na Assembléia Geral. Borges da Fonseca exigia o voto livree universal do povo brasileiro; o trabalho como garantia de vida para o cidadão brasileiro; o comércio a retalho só para os cidadãos brasileiros; extinção da lei do juro convencional; extinção do atual sistema de recrutamento e, é claro, a nacionalização do comércio a retalho. Essa lista de reivindicações está contida no manifesto que publicou na povoação de Limoeiro, pretenciosamente chamado de Ao Mundo (Autos, pp. 107-109).

A contemporaneidade de algumas dessas reivindicações teria um impacto sobre a historiografia do século XX. Em livro publicado originalmente em 1933, Caio Prado Jr. considerava a Praieira o último dentre os movimentos de caráter eminentemente popular e democrático que acompanharam o processo de Independência. Para ele, não faltou aos praieiros uma ideologia concreta e reformista, consignada nas reivindicações do manifesto Ao Mundo, que teriam sido covardemente renegadas pelos chefes da Praia depois da derrota da rebelião. Concordando com Nabuco, Caio Prado Júnior considerava que a nacionalização do comércio a retalho era uma das maiores aspirações do povo brasileiro. Em Pernambuco, a historiografia foi marcada pela celebração do centenário da Praieira em 1948. Como Isabel Marson bem observou, Amaro Quintas, Edison Carneiro e Barbosa Lima Sobrinho foram influenciados pelo clima pós-Segunda Guerra Mundial, e empregando uma retórica liberal radical tomaram uma posição pró-Praieira, assumindo como verdadeiro o discurso panfletário da imprensa liberal radical pernambucana. De acordo com Marson, os praieiros eram retratados como revolucionários legítimos, representantes do novo. Borges da Fonseca, um sans-culotte. A Praieira seria a fracassada revolução burguesa brasileira, nas palavras de Edison Carneiro (que, paradoxalmente, descreveu minuciosamente a Guerra do Mo- 
raes). Por sua vez, os conservadores (guabirus, em Pernambuco) eram descritos de forma anacrônica: verdadeiros reacionários, incapazes de atender às necessidades da população. A historiografia recente acolheu essa crítica de Marson, reconhecendo o caráter frentista da rebelião, cujo papel fundamental foi desempenhado por senhores-de-engenho, como aliás já havia sugerido Barbosa Lima Sobrinho ao discutir as teses de Quintas e Carneiro ${ }^{16}$.

Admitir o caráter frentista do movimento foi um grande avanço para o entendimento da Praieira. Todavia, o problema da presença (ou não) das classes subalternas nessa aliança permanece em aberto. Dentro de uma perspectiva temporal mais ampla, observa-se facilmente que entre 1832 e o advento do movimento abolicionista nos anos 70, nunca a população subalterna do Recife foi tão presente na política como entre 1844 e 1848. Mesmo assumindo que tenha sido modesta a participação das camadas subalternas na guerra civil de 1848-49 — o que por si é uma proposta arriscada —, essa constatação pouco explica a mobilização dos anos quarenta. E falar em diminuta participação é admitir que ela existiu. Era legítima a preocupação dos historiadores, cinqüenta anos atrás, em tentar explicar a mobilização popular naqueles anos. A mobilização da populaça do Recife não pode ser relegada à poeira do esquecimento apenas porque a Revolusão de Novembro terminou sendo uma face menor do que desejava Borges da Fonseca no poliedro de significados que foi o 1848 pernambucano. Retomando este assunto, é possível acrescentar mais uma camada de significado aos atos do tal povo do Recife naquele momento de perigo para todos os envolvidos.

\section{Clientelismo e DesobediênCias, ou o povo na Praieira}

De uma forma genérica, a presença dos grupos subalternos naqueles episódios poderia ser explicada dentro dos moldes permitidos pelos laços de dependência pessoal vigentes em uma sociedade escravista. De fato, no período em tela, as malhas do clientelismo enredavam-se entre os demais contextos relacionais. Mas constatar isto é apenas o ponto de partida para se explicar a ação da massa e não o ponto de chegada. O clientelismo não é um dado auto-evidente, muito menos um sistema com funcionamento regular e uniforme através dos tempos. Ao contrário, trata-se de uma conflituosa relação social e, como tal, dinâmica e em permanente interação com as relações de classe e raça, também condicionadas entre si e inseridas no tempo e no espaço. $\mathrm{O}$ clientelismo não é um dado estático e sim o produto de um longo conflito, mesmo que sua essência seja a busca de uma conciliação, tendo no patrão o principal beneficiário. Trata-se, então, de uma malha de relações entre partes desiguais. Tanto o dependente como o patrão têm suas próprias interpreta- 
ções do tenso contexto relacional em que estão imersos. É preciso, portanto, abordar o problema de forma dialética.

Apesar da tensão, há pontos de encontro entre as percepções que as partes envolvidas têm da relação, caso contrário não haveria nenhuma interação entre elas. Restaria apenas a guerra em lugar do atrito permanente das relações patronais. Uma vez estabelecido um eixo comum, um quid pro quo inicial, os feixes de interesses que ali se encontraram tomam direções distintas. $\mathrm{Na}$ experiência cotidiana, o chefe político tenta impor seu poder, sua visão de mundo. Mas o cliente não se adapta simplesmente às pressões advindas da camada superior da hierarquia patronal. Ele busca agir e pensar também a seu modo. Reinterpreta a noção patronal dos laços de clientela. Tenta, se não impor a sua visão, ao menos influir no processo, pressionando ou persuadindo seu patrão, por mais humilde que seja sua retórica. Nessa negociação entre partes desiguais, o lado mais fraco busca garantir direitos já adquiridos, e se possível expandi-los. O caráter pessoal dessa interação reforça as relações patronais tornando-as mais flexíveis e duráveis. Mas, contraditoriamente, a pessoalidade dos laços também impõe limites às imposições senhoriais, na medida em que todo o contato entre as partes é mediado por noções de honra, respeito e afetividade, resultantes de séculos de interação. Do conflito dessas percepções opostas resulta o clientelismo real, no qual o poder de mando do senhor nem sempre é absoluto e o cliente muito freqüentemente, mas nem sempre, obedece totalmente. Esse contexto relacional contraditório e dinâmico deve ser analisado no campo e na cidade no momento dos eventos em tela em lugar de ser tomado como um dado atemporal auto-explicativo.

Vale salientar que durante um conflito entre proprietários - Guerra do Moraes, por exemplo —, a posição do trabalhador-soldado poderia melhorar no processo de negociação com o patrão, piorando nos momentos em que a classe senhorial se encontrasse coesa. A autonomia do dependente era severamente restringida. Mas dentro do espaço de manobra que lhe restava, por limitado que fosse, não apenas respondia, mas em determinadas circunstâncias reivindicava, tentando alcançar o que normalmente lhe era vedado. Quando armado, mesmo servindo ao senhor, seu poder de barganha e os ganhos esperados certamente eram maiores do que no cotidiano do engenho de cana, onde o valor do trabalho era achatado pelo controle da terra e pela disponibilidade de escravos. Era nesses instantes de perigo que os laços patronais, sempre conciliatórios, podiam ser engolidos pela luta de classes.

Dessa dinâmica resultavam diferentes graus de dependência tanto no campo como na cidade.

Nas vilas e povoações do interior, a ameaça de recrutamento, prisão e espancamento desencorajava atitudes independentes. No campo, há muito se sabia que tanto lavradores quanto moradores de condição tinham apenas uma 
precária posse da terra. Em troca de seu uso era exigida obediência. Mas olhando da perspectiva dos grupos subalternos, havia exceções à regra. Era para evitar contestações que, em épocas de eleições, os proprietários rurais obrigavam os seus dependentes a votar na sua chapa sob a ameaça de evicção. Mesmo assim a desobediência ocorria. Durante o governo praieiro, por exemplo, alguns proprietários rurais ligados ao Partido Conservador expulsaram moradores de seus engenhos porque não votaram nos seus candidatos, conforme asseverou o próprio ministro da Justiça, ligado aos conservadores pernambucanos ${ }^{17}$.

Votar no candidato do senhor, contudo, não envolvia um risco de vida direto. Da perspectiva da população rural, a situação se complicava muito quando o dono da terra exigia a participação em manobras militares, como as que ocorreram na Guerra do Moraes. Isto era particularmente problemático numa província ensangüentada pela Insurreição de 1817, pela Confederação do Equador (1824) e pela Cabanada (1832-35). Mortes, fome, castigos corporais, humilhações diversas e o recrutamentos dos envolvidos deviam estar frescos na memória popular em 1848. Era preciso pesar bem as vantagens e desvantagens da obediência. Interrogado pelas autoridades, um pardo confessou sua participação na Praieira. Mas alegou que agira assim porque havia sido ameaçado de ser preso e despejado da terra. Muitos outros devem ter tomado a mesma atitude, temendo a evicção. Mas também houve aqueles que, sabendo dos riscos envolvidos, não se submeteram. Obedecer ao senhor nem sempre era compensador. Um agricultor declarou no inquérito que, junto com outros guardas nacionais, negou-se a seguir os proprietários da região em que viviam, porque ... contra o governo não marchavam ... Um comandante praieiro teve o mesmo problema na sua área de influência e terminou se queixando amargamente ao seu superior de um emigrado que vive fazendo calar o povo, dizendo que os seguidores dos praieiros marcham contra o governo, tornando-se todos criminosos. Por essa razão não conseguia reunir tropa. Agiram certo os desobedientes, pois, tal como em 1817 e 1824, os soldados anônimos vinculados às lideranças rebeldes seriam as maiores vítimas da repressão, cujos relatórios indicam o recrutamento de centenas de homens. Comentando o Código Penal do Império, um jurista falou que uns três mil cidadãos teriam sido deportados de Pernambuco por conta da Praieira ${ }^{18}$.

No momento em que as elites estavam cindidas, o dependente poderia vir a ser requisitado pelas facções em contenda. Sua obediência ou contestação era parte de um complexo jogo pela sobrevivência. Eventualmente, a vantagem poderia ser dele, que conseguia evitar a evicção e o recrutamento. Uma testemunha contra os praieiros era morador do engenho Tapera de um aliado dos conservadores, mas afirmou que outrora fora morador do engenho União, uma das principais bases de apoio à rebelião na Zona da Mata ${ }^{19}$. O par- 
do Amaro Joaquim de Oliveira Albuquerque havia, portanto, mudado de lado. De possível vítima de eviç̧ão terminou testemunha oficial, escapando também do recrutamento que arrastou muitos dos moradores dos engenhos dos praieiros. A mobilidade espacial da clientela rural, dessa maneira, poderia também ser um subproduto dos conflitos intra-elites nos quais os moradores dos engenhos eram chamados a atuar e nem sempre o faziam de acordo com o mando do chefe político imediato.

Apesar dessa possibilidade existir, não era fácil escapar do engajamento exigido pelo patronato político rural que, em geral, ainda mandava nas vilas e povoados do interior. Mas mesmo depois de engajado havia alternativas; afinal de contas, como tantas outras coisas na vida, a obediência não é um dado fixo, mas um ponto qualquer entre os limites de uma escala. Havia diferentes graus de obediência. Empunhar armas não significava ser um bom soldado. Qualquer leitura apressada dos relatórios das autoridades provinciais, ou da correspondência dos rebeldes praieiros, deixa claro o pouco entusiasmo dos guardas nacionais e tropas particulares envolvidos nos combates. As deserções eram muitas e praticamente impossíveis de conter. O general Coelho, comandante das Armas que esmagou a Praieira, relutava em entregar armas aos guardas nacionais, temendo as freqüentes deserções com o equipamento. A pena para os desertores da Guarda Nacional legalista era o recrutamento. Para os praieiros chegou a ser a morte ${ }^{20}$.

Nesse jogo, a desobediência podia não ser passiva nem pacífica. Não era fácil controlar a clientela armada. O engenho Maranhão sofreu depredações da tropa legalista, mesmo sem pertencer a um rebelde. $O$ vice-presidente da província durante o governo praieiro, Francisco Honório Bezerra de Menezes, ao ser visitado em seu engenho por uma coluna praieira, teve que distribuir 300 mil réis à tropa, temendo que sua propriedade fosse queimada ${ }^{21}$. Os feitos militares sempre foram um meio de ascensão social através da história. No auge da refrega, é natural que algumas posições de comando fossem conquistadas por homens que entraram na revolta como dependentes, mas que à medida que o tempo passava e o sangue vertia, ganharam uma autonomia nem sempre desejada por seus chefes originais. Para estas novas lideranças surgidas no calor dos combates, o saque era um atrativo que poderia ameaçar proprietários de qualquer faç̧ão.

O caso do engenho Aguiar serve de exemplo. Em janeiro de 1849, uma coluna praieira foi lá tomar as armas e certamente punir o proprietário, que havia socorrido os soldados feridos no ataque ao engenho do coronel Moraes. Segundo Figueira de Mello, houve roubos e insultos à família do proprietário. Mas o pior ainda estaria por vir. Pouco depois, chegou uma segunda coluna, comandada pelo crioulo Elias, feito tenente, depois capitão das tropas praieiras. Não faltou violência. Foram mortos alguns moradores e pe- 
lo menos um dos filhos do proprietário, que ainda foi seqüestrado junto com o genro, sendo solto cinco dias depois. Este episódio foi usado por Figueira de Mello para desmoralizar os praieiros e embaraçar sua defesa, uma vez que eles alegavam ser proprietários respeitáveis que apenas queriam se proteger dos seus inimigos guabirus. Todavia, os próprios praieiros não se sentiram confortáveis com o que ocorrera durante o ataque comandado pelo crioulo Elias. O comandante da primeira expedição contra o engenho foi preso. Ao depor nos autos, admitiu que conduziu 40 homens na operação, a mando do coronel Moraes. Mas fez questão de enfatizar que não participou da segunda força que atacou a propriedade, e que cometera diferentes assassinatos em pessoas do mesmo engenho ${ }^{22}$.

Episódios emblemáticos como esses servem para mostrar os limites da obediência. Mesmo o mais humilde morador de condição um dia poderia transgredir, tanto por medo, desertando, como por ambição, roubando e atacando quem não deveria. Mas em todos os momentos seus atos eram regidos por seus interesses, seus temores, suas interpretações do momento. Havia uma noção de legitimidade forjada na dinâmica da luta de classes. Cada gesto era medido, pois a vida é sempre preciosa. No Recife, as relações clientelísticas também tinham contradições. Só que, no perímetro urbano, os praieiros tinham uma reivindicação concreta para atrair a lealdade do povo: a nacionalização do comércio a retalho.

Para avaliar o impacto dessa proposta nativista é preciso uma breve discussão sobre as fontes aqui empregadas. Como se viu acima, os participantes que deixaram seus pensamentos escritos consideravam que o governo praieiro tinha o apoio das camadas subalternas. Segundo Isabel Marson, o livro de memórias do chefe de polícia que reprimiu a Praieira foi o que mais marcou a historiografia tradicional, que teria exagerado a participação popular na rebelião. Figueira de Mello reordenou os fatos, recriando a Praieira dentro do imaginário dos vencedores, deturpando a cronologia real dos acontecimentos e imputando ao partido praieiro posições que ele não tinha.

Entretanto, não foi somente a Crônica da Rebelião Praieira que o Chefe de Polícia Figueira de Mello produziu. Ele também foi a autoridade que organizou o inquérito policial contra os rebeldes. Paradoxalmente, os autos do inquérito servem de contraponto ao livro de memórias que ele mesmo escreveu depois. O motivo para esse paradoxo é simples: as intenções do autor do inquérito haviam mudado no momento em que resolveu escrever suas memórias sobre a Praieira.

$\mathrm{Na}$ Crônica, Figueira de Mello ligou os praieiros às classes perigosas do Recife porque queria demonstrar que o movimento não defendia os interesses dos homens ricos e respeitáveis da província. Todavia, um ano antes, quando preparava o inquérito policial, precisava demonstrar que a população ur- 
bana não se envolveu na rebelião, pois de acordo com o Código de Processo Criminal, caso a população da capital estivesse rebelada o julgamento deveria ser transferido para da fora província. Nem Figueira de Mello nem os líderes do Partido Conservador queriam isso. Em outra província, com outros jurados e juiz conduzindo o julgamento, os praieiros teriam melhores chances de defesa. Por esta razão, o inquérito foi organizado para pronunciar os praieiros pelo crime de rebelião no interior, mas isentava a população urbana de uma participação mais ativa nos acontecimentos. O libelo acusatório dizia que sete povoações contendo mais de vinte mil pessoas haviam se rebelado, mas excluía Recife e Olinda desta relação, apesar do combate do dia dois de fevereiro de 1849 no Recife, quando morreram centenas de pessoas. A defesa praieira, ao contrário, alegou a incompetência do tribunal (presidido pelo pai de Joaquim Nabuco) para conduzir o caso, argumentando que Recife e Olinda haviam se rebelado, devendo o julgamento ser transferido para outra província $^{23}$. O inquérito policial, portanto, foi construído para condenar os praieiros pelo crime de rebelião, mas isentando a população urbana de qualquer participação significativa nos eventos. Está claro o paradoxo: os autos do inquérito contradizem o livro de memórias do mesmo chefe de polícia que o organizou. $\mathrm{O}$ confronto entre esses textos, com o apoio de mais alguns documentos, permite conhecer melhor a participação daquilo que as fontes chamavam de povo.

Quem era esse povo do Recife? Para os liberais pernambucanos, nele não estavam incluídos os escravos, os mendigos, os índios, os livres e libertos que nada tinham de seu. Era preciso um mínimo de bens. Borges da Fonseca não chegou ao exagero de uma folha conservadora, O Capibaribe, que chamou a multidão que fez o mata-marinheiro de junho de 1848, de fezes da sociedade. Mas n'O Tribuno, distinguiu claramente o povo dos negros e moleques ${ }^{24}$. No vintismo lusitano já estava em construção uma noção de povo, como pressuposto para a própria existência do rei. Esta noção seria instrumental para os liberais brasileiros em diversos momentos da história imperial. Contudo, as idéias iluministas não entravam no Brasil sem arranhões. Era preciso ajustes conceituais em função da conjuntura, do contexto, das práticas do cotidiano. No Brasil, a noção de povo tinha um caráter ainda menos abrangente do que em países rigidamente hierarquizados mas sem escravidão ${ }^{25}$. Na concepção dos liberais moderados de Pernambuco, o povo incluía apenas os livres em condições acima da simples subsistência que poderiam atuar politicamente como guardas nacionais ou como votantes.

Esse povo não agia sem alguma forma de direção. Ao apontar os possíveis culpados, o inquérito tinha que ser seletivo. Só a liderança interessava à lei. Era impossível incriminar os vinte mil habitantes envolvidos no crime de rebelião. O Código Penal punia apenas os cabeças de rebelião. Por essa razão, 
nem o crioulo Fidelis Carneiro, que ajudou a atrair gente em Olinda, nem o pardo Rogério, que subiu ao posto de alferes no exército praieiro, nem o crioulo Elias, já mencionado no ataque ao engenho Aguiar e que subiu de tenente a capitão no exército praieiro, nem João Bilro, desordeiro bem conhecido, entretendo o espírito de resistência nas classes baixas da população, nem Pedro Abissinio, acusado de levar um baú de remédios para os rebeldes, tiveram seus atos descritos com mais detalhes no inquérito ${ }^{26}$.

O tal povo, ao qual se referiu Nabuco, só podia aparecer na documentação através de seus cabeças no meio urbano e rural. Somente os líderes mais evidentes interessavam à burocracia judicial. Para atuar na nascente política partidária essas lideranças não poderiam ser compostas de miseráveis ou de escravos, embora, quem sabe, possa até ter havido alguns, guindados a postos de comando pela destreza na arte da guerra. Sendo um agente mediador de negociações complexas, o líder popular atuava na fronteira entre a camada social da qual procedia e o estrato superior, ao qual ele poderia ou não ascender. Agindo nessa posição, entre uma camada social e outra, poderia propor alternativas ou transigir, sem perder o vínculo com suas raízes sociais. Mas para sair do anonimato e subir a essa posição, era preciso um mínimo de propriedade, uma profissão, algum meio de vida. Era assim com os reis do Congo, com os provedores das irmandades negras, com os pardos e negros que ascendiam nos escalões militares. Não poderia ser diferente entre brasileiros natos que trabalhavam no comércio urbano, muitos dos quais, embora homens modestos, estavam legalmente habilitados a votar ou mesmo a serem votados.

Era preciso ainda que fossem politizados o suficiente para entender as principais diferenças entre os partidos a ponto de simpatizarem com os praieiros, ou com as propostas mais radicais de Borges da Fonseca, e ainda fazerem a transposição do discurso político-partidário para seus liderados. Tornavamse intelectuais na acepção gramsciana do termo, ou seja, agentes capazes de dar um direcionamento ideológico às ações do grupo. Quando mobilizados pelos praieiros, o foram como oficiais da Guarda Nacional. E o oficialato da Guarda Nacional era formado por eleitores. A partir dessas posições tinham acesso ao estrato superior, permitindo-lhes negociar em favor do grupo ao qual pertenciam. Eram homens que detinham um certo grau de respeitabilidade. No mínimo faziam parte daquela camada que Peter Beattie chamou com precisão de pobres honrados (honorable poor). Ou seja, não eram ricos, mas certamente tinham meios de viver sobre si, como se dizia na época, e não estavam sujeitos ao recrutamento ${ }^{27}$.

Alguns desses indivíduos aparecem nas fontes. Um deles foi Manoel Romão, lavrador das terras do engenho Poeta, na freguesia da Várzea, subúrbio do Recife. De acordo com o inquérito, ele havia sido um dos principais agen- 
tes instigadores da revolta naquela freguesia. Para uma testemunha, Romão e seu irmão eram públicos sedutores dos povos. Outra testemunha acusou-o de participar dos clubes na casa de um líder praieiro no Recife, o negociante de madeira José Higino de Miranda, um dos encarregados de aprovisionar as tropas rebeldes. O chefe de polícia explicou essa desenvoltura: Romão tinha tomado certo ascendente sobre os homens de cor ao tempo da dominação praiei$r a$. De fato, durante a rebelião, tornou-se tenente-coronel do exército praieiro, ombreando-se assim aos senhores de engenho rebeldes mais prósperos. Comprovadamente chegou a comandar 52 homens. Um feito sem dúvida. Romão foi preso e pronunciado como cabeça de rebelião, mas infelizmente não lhe deram chance de falar no inquérito, se é que sobreviveu à revolta ${ }^{28}$.

Esse povo incluía no seu topo pequenos negociantes do Recife e do interior, além de trabalhadores especializados, semi-especializados e funcionários públicos. Juntos formavam o substrato das camadas médias baixas ainda em ebulição. Na documentação legada pela repressão fica clara a presença de indivíduos advindos desses estratos, inclusive funcionários do aparato burocrático, militares e padres. Há indivíduos ativos na rebelião que não são desempregados, mas também não são tratados por doutor ou bacharel, atestados se não de sapiência, ao menos de berço farto numa sociedade onde dificilmente um pobre qualquer conseguiria estudar Direito.

As fontes denunciam 15 funcionários ligados aos escalões médios e baixos do aparato estatal, dos quais ao menos 12 foram detidos. Descontado qualquer idealismo, no mínimo estavam defendendo o emprego que tinham, já que a circular Alves Branco sobre fidelidade partidária de 1846 autorizara os governos provinciais a demitir funcionários quando havia uma troca de gabinetes. O inquérito acusa professores de primeiras letras, contadores de tesouraria, secretários, porteiros, escriturários de repartições, um fiel do Consulado Provincial e guardas de repartições. As testemunhas os incluíam entre os rebeldes e sedutores de povos. Das residências de pelo menos três desses funcionários foram disparados tiros contra a tropa do governo durante a invasão do Recife pela tropa praieira. O oficial mor da Tesouraria da Fazenda, João Fernandes da Cruz, foi acusado de participar de reuniões sediciosas e assumir o posto de alferes nas tropas rebeldes. O mais grave, todavia, foram os depoimentos de seis testemunhas que viram tiros sendo desferidos nas tropas do governo a partir de sua casa. Da casa do guarda da Alfândega Muniz também se atirou nas forças legais. Dentro dela foram presos vários rebeldes ao findar o combate. Francisco José do Rego, escrivão da justiça civil, não só participou da rebelião como foi acusado de ter ajudado a transportar munições para o interior. Uma carta de um comerciante praieiro apreendida fala que Francisco o ajudara a pressionar o fornecedor a aumentar a remessa de pólvora para os praieiros. Da casa dele também se atirou contra as tropas impe- 
riais. Francisco José do Rego foi ainda acusado de ser agente de subscrições e pertencente a clubes da Bahia, e terminou sendo um dos poucos indivíduos efetivamente pronunciados no inquérito como cabeça de rebelião ${ }^{29}$.

Com relação aos trabalhadores especializados e semi-especializados, vale lembrar mais uma vez que o inquérito pouco se preocupou com os simples participantes, assim não é possível esperar que fossem definidas nas fontes a profissão de cada um dos detidos listados nos Autos do Inquérito ou no livro do deputado praieiro Urbano Sabino Pessoa de Mello. Para a sorte dos historiadores, alguns dos mais ativos são melhor qualificados. Ao menos vinte e dois artesãos são acusados explicitamente nas fontes. Dezenove foram efetivamente presos, oito dos quais no Recife. Entre eles estava o negro ou crioulo Cecílio, um oficial de sapateiro. Três testemunhas o acusaram, mas não sabiam seu sobrenome. Sabiam porém que havia lutado como capitão nas forças rebeldes, o que foi confirmado pelos documentos apreendidos pela polícia ${ }^{30}$.

Dois funileiros e um ferreiro foram listados entre os participantes. Os funileiros foram efetivamente detidos, mas apenas um deles morava no Recife. De acordo com uma testemunha, Geraldo Amarante dos Santos era um ativo sedutor de povos e costumava fazer reuniões sediciosas em sua loja ${ }^{31}$.

Dentre os artesãos, os alfaiates foram o grupo mais ativo na revolta. Pelo menos sete são nomeados nas fontes, que ainda mencionam outros. Cinco chegaram a ser presos. Dois no Recife. Um em Itapissuma. Os demais as fontes não dizem onde. $\mathrm{O}$ alfaiate Manoel Joaquim da Costa foi acusado por três testemunhas de fazer reuniões em sua loja. Quando o exército praieiro tentou tomar o Recife, de sua casa foram desferidos tiros nas tropas imperiais. Segundo uma testemunha, o mesmo ocorreu na casa na Rua do Queimado, onde moravam o alfaiate José Romão de Freitas e outros. Estes homens também atuaram como sedutores de povos. Da casa de outro alfaiate, Manoel do Amparo Caju, também se atirou nas tropas do governo. Muito influído pela causa dos rebeldes (sic), o pardo Caju tinha prestígio suficiente para ser votado eleitor no Recife, com o apoio de Borges da Fonseca. Não era o único alfaiate indiciado que não era branco. Era preto o alfaiate Luiz Hamburgo, esperado por um grupo que saía do Recife para juntar-se aos rebeldes reunidos em Igarassu. Cabe lembrar ainda que talvez houvesse outros negros livres envolvidos, pois o Divino Mestre, defendido por Borges da Fonseca em 1846, era um alfaiate, e segundo seus adversários, teria uns 300 seguidores entre os negros da cidade ${ }^{32}$.

Não há líderes sem seguidores. Essa amostra, portanto, permite entrever que as opiniões do visconde de Camaragibe, ou de Nabuco, sobre a presença dos grupos subalternos na Praieira, não eram totalmente infundadas. Amaro Quintas enfatizou a influência do socialismo utópico na insurreição. Isabel Marson ponderou que esta proposição era um exagero não confirmado pelas 
fontes. É preciso, portanto, buscar outras motivações para a mobilização da população urbana naqueles anos. O povo não era formado por gente dócil e obediente. Os homens que se arriscaram participando de reuniões sediciosas, dando tiros nas tropas imperiais a partir de suas próprias casas e lojas, não eram apenas clientes obedientes sem objetivos próprios na revolta.

\section{MobILIZAÇÃo, MotivaÇÕes, LeGITIMIDADE}

Como explicar a participação dessa parcela do povo do Recife?

A primeira coisa que vem à mente são as oportunidades de lucro abertas numa situação dessas, quando homens conhecidos pela destreza nas armas e na luta corporal eram contratados pelo patronato rural e urbano. De acordo com o pescador Antônio José Rodrigues, aqueles que se juntavam aos rebeldes recebiam uma quantia, cujo máximo nunca excedera quatro mil réis ${ }^{33}$. Este máximo não é tanto assim se considerarmos que, legalmente, os guardas nacionais deveriam ser pagos ao servirem fora do município de origem por mais de três dias. Além disso, todos, e não apenas os praieiros, ofereciam dinheiro à tropa. Durante o governo praieiro, um senhor do lado conservador teria pago 500 réis diários aos seus jagunços para defendê-lo da polícia praieira. Em menos de dez dias, portanto, tem-se mais do que o máximo reservado aos rebeldes em 1848. O general Coelho, por sua vez, pediu 170 réis diários para a simples manutenção dos guardas nacionais que combatiam a rebelião. Já os 95 praças da guerrilha que deixou para combater os insurgentes ao norte do Recife, percebiam mil réis diários. Escrevendo na década de 1840, Antônio Pedro de Figueredo afirmou que o jornal de um artesão variava em média de 320 a 480 réis diários. A construção do Teatro Santa Isabel provavelmente ocupou boa parte da nata do artesanato local. O salário mais baixo na obra, em 1838, era reservado aos piconeiros, que recebiam 540 réis por dia. Em 1842, a Tesouraria Provincial calculava em 560 réis o jornal diário de dois pretos serventes $^{34}$. Com esses referenciais em mente, fica difícil considerar que quatro mil réis, o máximo, repito, que teria sido pago pelos praieiros, pudesse ser a única razão para a adesão de tantos ante os riscos envolvidos. Como disse Paulinho da Viola, "dinheiro na mão é vendaval". Mas tão pouco assim não era o bastante. $O$ pagamento era relevante, principalmente em longas diligências na Guarda Nacional. Contudo não era o suficiente para se dar tiro nas tropas imperiais, fardadas e empunhando bandeiras e armas de uso exclusivo das tropas de primeira linha.

A chave para se entender a ação da população engajada na revolta está na radicalização das disputas eleitorais na província. Aponta com precisão Jeffrey Mosher, que a novidade das eleições de 1844 foi a organização de reu- 
niões públicas de votantes e eleitores, os meetings, termo aliás que os jornais coevos eventualmente utilizavam na falta de uma tradução exata na época. $\mathrm{O}$ candidato conservador, o barão da Boa Vista, foi o primeiro a promover um evento deste tipo, possivelmente uma importação a mais entre as tantas que trouxe da França, onde estudou antes de tornar-se presidente da província (1837-1844). Estava inaugurada uma nova prática que seria um dos pilares da futura cultura política do século XX. Só que os praieiros logo adotaram a receita, sendo mais bem-sucedidos em mobilizar adeptos, resultando em verdadeiros comícios em que o alcance da voz era o único limite ao tamanho da multidão. Não foram poucas as ocasiões em que a mobilização eleitoral resultou em brigas, quebra-quebras e correrias ${ }^{35}$.

Além do fecha-fecha de 1844, houve pelo menos cinco manifestações violentas no Recife entre 1845 e 1848 . Os mata-marinheiros foram assunto de todos os livros sobre a Praieira. Houve espancamentos, roubos, alaridos e mortes. Como disse o cônsul português no Recife: a plebe (...) nessas ocasiões é soberana ${ }^{36}$. Há um ponto em comum em todas essas manifestações: a principal reivindicação da populaça do Recife era a nacionalização do comércio a retalho. A multidão participou ainda de duas marchas (uma em 1844, outra em 1848) em direção à Assembléia Provincial, levando abaixo-assinados exigindo a expulsão dos portugueses solteiros e a nacionalização do comércio a retalho. Ambos os abaixo-assinados foram promovidos pela Associação dos Artistas Pernambucanos, que recebia um modesto subsídio do governo praieiro para sua sobrevivência. Os artistas mecânicos — os artífices da província — já tinham portanto uma associação para representá-los. Para os jornais de ambos os partidos, as passeatas de 1844 e 1848 envolveram em torno de duas mil pessoas ${ }^{37}$. O que significavam duas mil pessoas reunidas nas ruas do Recife em meados dos anos 1840 ?

Uma contagem publicada em janeiro de 1856 dava ao termo do Recife 44.371 habitantes entre livres e libertos, além de 10.382 escravos. Levando-se em conta que a participação ostensiva nos rituais políticos públicos era quase um monopólio dos homens livres e libertos adultos, pode-se afirmar que duas mil pessoas formavam uma multidão considerável para os padrões do Recife oitocentista. Simplificando, excluindo os cativos e as mulheres em geral, e assumindo que um terço dos homens ou eram muito velhos, novos ou impedidos de participar, restariam uns quinze mil homens espalhados por uma cidade onde inexistia um sistema de transporte de massa para levá-los ao centro onde ocorreu a manifestação. Treze por cento deles compareceram. Esses dados ficam ainda mais contundentes se usarmos como referencial o fato de que nos bairros listados em 1856 havia apenas 6.029 votantes em $1842^{38}$. É como se hoje em dia uma manifestação juntasse um terço da população votante do Recife $^{39}$. O direito de petição era uma prática consagrada desde o período co- 
lonial. Mas acompanhada de uma manifestação de rua dessa dimensão era o sintoma de uma significativa mudança na cultura política local.

A principal reivindicação dessa gente toda era a nacionalização do comércio a retalho. Propor a expulsão de portugueses, ou ao menos excluí-los do comércio miúdo, eram propostas nativistas que durante a Sabinada na Bahia já haviam catalizado o apoio popular. O nativismo nasceu nas Américas como um instrumento ideológico a serviço das elites crioulas, aglutinando em um nível ideal grupos sociais em condições distintas ou mesmo opostas. A construção dessa noção não implicava apenas excluir estrangeiros. O mais importante era a maneira como os demais eram assimilados. Ao amalgamar brancos, negros e mestiços livres nascidos no Brasil num bloco só, em oposição aos portugueses, o nativismo encobria diferenças mais profundas de raça, classe e condição legal. Isso sem falar no abismo cultural que separava os negros livres e libertos nascidos no Brasil, dos brancos das camadas dominantes. O discurso nativista dissolvia identidades profundamente enraizadas, colando os desiguais em face da utopia do Estado-nação provedor de direitos.

Como se não bastasse esta contradição, os principais excluídos, os portugueses solteiros agredidos nos mata-marinheiros, embora brancos, geralmente eram pobres e nem sempre europeus, mas imigrantes das ilhas atlânticas do vasto império ultramarino lusitano, atraídos por parentes e conterrâneos que formavam uma ampla rede de contatos, repassando informações sobre oportunidades de emprego. Nos jornais da década de 1840 não faltam anunciantes em busca de caixeiros, dando preferência a jovens entre doze e catorze anos recém-chegados ao Brasil. Era dura a vida desses adolescentes e poucas as oportunidades de mobilidade social. Mas ao menos arrumavam trabalho e iam tocando suas vidas, para inveja de muitos brasileiros espremidos entre a escravidão e o inerte bolor do desemprego, já que as camadas superiores não os consideravam brancos e preferiam imigrantes europeus para qualquer serviço que não fosse próprio de escravos.

O paradoxo é que muitos deles vieram em situação tão vexatória que a diplomacia portuguesa chamou de tráfico de escravatura branca a forma como viajavam para Pernambuco. Patrocinados por negociantes brasileiros, portugueses e ilhéus, os navios enchiam-se de gente - muito além do que permitia a tonelagem e o calado - e partiam. Ao chegarem no Recife, só era permitido o desembarque daqueles cujas passagens eram saldadas por proprietários interessados em contratar seus serviços. O sistema assemelhava-se ao caso dos indentured servants da América do Norte, mas sem freedom dues nem nada equivalente. Levados para o interior, ficavam impossibilitados de procurar outro patrão até saldarem o valor da passagem, sempre muito acima do preço de mercado. Alguns dos que fugiram foram anunciados nos jornais. De acordo com o cônsul português, os próprios imigrantes chegaram a 
redigir protestos contra a forma como eram tratados. Esse tráfico de escravatura branca ocorria em pleno governo praieiro e continuaria depois ${ }^{40}$.

Olhando através do prisma do século XXI, é fácil imputar ao sistema escravista, ao latifúndio, à monocultura, a culpa pela falta de oportunidades para os homens livres pobres. E isso até alguns intelectuais coevos, como Antônio Pedro de Figueredo e Borges da Fonseca, entendiam bem. Mas seria anacrônico pensar que estas elaborações teóricas eram compartilhadas pelo povo do Recife nos anos 1840. Nem sempre os grupos dominantes eram o primeiro alvo do descontentamento dos trabalhadores urbanos ${ }^{41}$. Para os contemporâneos devia ser praticamente impossível abstrair a situação imediata: o desemprego, os embaraços da moeda falsa sobre o comércio a retalho, a carestia que sempre atingiu as inchadas cidades brasileiras. Imerso nesses problemas, devia ser duro para alguém endividado com algum seu Manoel do armazém, ver um adolescente recém-chegado arrumar trabalho na padaria da esquina. Bastava surgir uma oportunidade para que a catarse popular estourasse. O discurso nativista radical de jornais, como $A$ Voz do Brasil, terminava encontrando quem estivesse disposto a ouvir, influenciando condutas, agitando a população contra os empregados estrangeiros. A violência do mata-marinheiro de junho de 1848 foi tamanha que pela primeira vez na história de Pernambuco, um grupo de 177 imigrantes pediu ajuda da Coroa lusitana para deixar o Brasil e fundar uma nova colônia em Moçâmedes, Angola. À frente deles estava Bernardino Freyre de Abreu e Castro, o autor do primeiro romance cuja história se passava no Recife. Em 1850, mais cem pessoas tomaram o mesmo rumo. Mesmo brancos, não encontraram a riqueza no Brasi ${ }^{42}$.

Até certo ponto as manifestações antilusitanas mais violentas foram toleradas, ou mesmo encorajadas, pelo governo praieiro. Mas só até certo ponto, pois a tal plebe soberana, como diria o cônsul português, tomava as ruas e aí ninguém controlava mais coisa nenhuma. Foi esta a queixa do cônsul britânico ao governo praieiro, quando um inglês foi espancado por um grupo de pardos e negros, que fugiu ao aproximar-se a polícia comandada pelo delegado do bairro, José Higino de Miranda — o mesmo negociante que promovia reuniões em sua loja e que viria a fornecer munição aos rebeldes. Só que, espertamente, o inglês conseguiu segurar um dos agressores. Para sua decepção, teve que soltá-lo ao ouvir o delegado dizer-lhe que nada poderia fazer a esse respeito ${ }^{43}$. Este episódio, envolvendo um estrangeiro e um negociante de madeira ungido delegado, demonstra a insegurança reinante durante um mata-marinheiro.

Dizer que os praieiros eram lídimos representantes dos anseios populares é um exagero desnecessário. Na realidade, o que havia entre as lideranças partidárias e as lideranças das camadas subalternas era uma convergência de interesses conjunturais, levando mediadores entre o mundo do trabalho livre 
e uma facção das elites locais a agirem em conjunto, mas sem perderem o vínculo com suas respectivas bases. A mobilização dos artistas mecânicos, de homens livres em busca de oportunidades, foi facilitada pela conjuntura que dividiu as elites, criando um espaço no cenário político maior onde esses agentes podiam expressar ao menos uma parte dos seus anseios. Todavia, essas lideranças não dependiam completamente dos chefes praieiros. Pode-se especular que havia um certo grau de autonomia corporativista entre os trabalhadores livres da cidade. As comunidades negras, apesar das restrições que lhes eram impostas, criaram hierarquias internas, organizaram-se em irmandades, cantos, nações, e eram regidas por reis do Congo e governadores de pretos. Não se pode estranhar as tentativas dos trabalhadores livres de se articularem de alguma forma. No seu cotidiano, vivenciavam as adaptações locais das tradições associativas importadas de Portugal durante o período colonial.

A Constituição de 1824 aboliu as corporações de ofício no Brasil para incentivar a vinda de artesãos que poderiam assim montar seus negócios com independência. A existência da escravidão dificultava a consolidação de associações cooperativas no Brasil análogas às que estavam aparecendo e se multiplicando na Europa no começo do século XIX, pois os artesãos mais hábeis terminavam virando donos de escravos. Mas havia alternativas locais que correspondiam ao contexto brasileiro. Nos autos da Praieira há indícios da existência de práticas organizacionais, que poderiam ser tímidas para os padrões europeus da época, mas eram suficientemente vivas para congregar trabalhadores. Havia uma associação de artistas mecânicos capaz de mobilizar a massa urbana numa manifestação em favor da nacionalização do comércio a retalho. Como se viu acima, ao menos na casa do funileiro Geraldo Amarante dos Santos havia reuniões sediciosas. Pode-se supor que nesses encontros, como era comum na época, devia haver leitura em voz alta de textos panfletários, permitindo a transposição do discurso político-partidário para os presentes, e deles para o resto da população. Não era só um artifício retórico das fontes chamar de sedutores dos povos o funileiro Geraldo Amarante dos Santos e os alfaiates acusados nos autos. Deve ter sido de alguma dessas reuniões que saíram as representações à Assembléia Provincial a favor da nacionalização do comércio a retalho.

As pessoas não buscam o vazio. Elas só se rebelam por ideais que acreditam poder atingir, por mais utópicos ou messiânicos que seus objetivos possam parecer quando observados através das céticas lentes das Ciências Sociais. O povo do Recife tinha uma motivação aparentemente viável: a nacionalização do comércio a retalho. O principal líder praieiro, o deputado Nunes Machado, levou essa reivindicação à Câmara, discutindo o assunto em junho de 1848 . Tendo ido tão longe, percebe-se que essa proposta não parecia tão utópica assim em 1848. O povo do Recife tinha uma noção de legitimidade construída a 
partir da experiência política concreta e dos contextos situacionais em que estava imerso. Os participantes acreditavam estar defendendo direitos legítimos e não apenas obedecendo aos oficiais superiores que os chamavam à revolta. $\mathrm{Ou}$ seja, os participantes obedeceram às ordens, mas dentro de um conceito próprio dos laços de clientela. Daí porque quando os riscos da rebelião ultrapassavam as expectativas dos ganhos com a vitória, eles desertavam, não obstante os salários oferecidos que certamente eram um atrativo, principalmente para quem estava desempregado. Um escritor da época, citado por Amaro Quintas (p. 38), entendeu bem a dialética do clientelismo: cumpre confessar que as massas que aderiram ao movimento de Pernambuco se houveram com tanto heroísmo, tanto calor, tanta dedicação, tanto desinteresse, que é mister que algum sentimento forte tivessem no coração e não fossem a simples obediência ao aceno de alguns quem os tenha empenhado na luta. A nacionalização do comércio a retalho foi a ponte ideal que ligou participantes de camadas sociais distintas. Foi a única reivindicação presente em todos os principais manifestos da revolta unificando os grupos que participaram na Praieira.

É esta reivindicação que estabelece o limite entre o que os indivíduos faziam devido ao lugar que ocupavam dentro da malha clientelística, daquilo que o grupo fazia seguindo seus líderes imediatos. Esta distinção entre clientelismo e liderança é importante neste contexto. Como foi dito acima, o clientelismo é uma relação assimétrica, enredada em outros contextos relacionais, entre os quais os de classe e raça formavam os feixes mais densos no Brasil imperial. Existe uma clara coerção econômica nesta conflituosa relação, já que o cliente, literalmente, depende de alguém do estrato superior da malha patronal, onde está o dono da terra ou o provedor do emprego público. Como quase sempre na vida, existe margem para negociação. O cliente busca ampliar este espaço, tentando convencer o patrão de que ele é necessário, que sua lealdade tem um preço e que portanto também tem direitos. Mas o cerne da relação, e fonte do conflito a ela inerente, é a coerção.

É justamente a coercibilidade inerente à relação entre o patrão e o cliente que a distingue da relação entre um líder e o liderado. O patrão comanda devido à posição que ocupa numa escala socioeconômica. O que lhe confere poder é a sua colocação num determinado ponto de uma hierarquia. Ele é obedecido graças à sua capacidade de conceder favores ou de empregar gente. As relações patronais são, por conseguinte, pessoais. A liderança é um contexto relacional diverso. É quase o inverso da relação patronal, porquanto o seu cerne é a aquiescência do liderado, que no caso age como membro de um grupo. É esta adesão voluntária que permite que o líder e o grupo façam algo juntos. As pessoas escolhem seus líderes com muito mais liberdade do que seus chefes e patrões. A liderança é uma relação entre o líder e o grupo, baseada na anuência dos liderados. Enganados ou não, eles seguem o líder, seja porque compar- 
tilham valores com ele, acreditam que a implementação de suas idéias irão beneficiá-los, seja apenas por causa dos laços afetivos com ele. Quanto mais carismático é o líder, mais ele se beneficia desses sentimentos do grupo ${ }^{44}$.

Pensemos agora nos líderes populares da Praieira, os artífices sedutores de povos, homens capazes de dirigir a ação dos demais. Entre eles e a haute politique partidária atuavam lideranças mais amplas — políticos que transitavam entre camadas sociais distintas, como o deputado Nunes Machado e o liberal radical Borges da Fonseca. A reivindicação comum, a nacionalização do comércio a retalho conseguiu transpor a tênue linha que separava as reivindicações raramente escritas das camadas subalternas de um conjunto de idéias facilmente encontradas em textos: a opinião pública. Para Roger Chartier, a opinião pública, que emergiu nas discussões na França revolucionária por volta de 1750, era praticamente o oposto do público, do popular. Era o resultado das elucubrações de estratos intelectualizados, o contrário da rude e deseducada massa ${ }^{45}$. A nacionalização do comércio a retalho atravessou esses dois universos. Foi defendida nas lojas dos artesãos, gritada nas ruas, transformada em petição patrocinada pela associação que congregava os artífices de Pernambuco, e finalmente proposta na Câmara, na capital do império por um grupo de deputados ligados ao imperador através da amizade pessoal que tinham com o visconde de Sepetiba, Aureliano de Souza Coutinho.

O deputado Nunes Machado teve um papel relevante nesse processo. Mesmo seus adversários o reconheciam como o político mais popular da província. Apesar dos combates terem começado em novembro, ele permaneceu no Recife até o final de dezembro de 1848, recrutando gente e arranjando dinheiro. Sua presença evitou o aumento das deserções, o que inviabilizaria a revolta. No interior, espalhou-se o boato de que havia sido nomeado presidente da província, mas não queriam deixá-lo assumir ${ }^{46}$. Era uma tentativa de apresentar a Guerra do Moraes como um capítulo a mais nas lutas eleitorais da classe senhorial. Havia apenas uma diferença: desta vez uma das facções incorporou em seu programa a nacionalização do comércio a retalho. Nada mais natural do que defender a posse de um novo presidente da província que apoiava esta reivindicação.

\section{CONCLUSÃO}

Pode-se dizer que logo abaixo de Nunes Machado ou Borges da Fonseca, havia líderes de trabalhadores especializados e semi-especializados, que conduziam seus seguidores norteados por uma noção de legitimidade clara e objetiva. Para eles, o alvo imediato não era o Estado imperial, mas aqueles que consideravam aliados dos portugueses que ocupavam os empregos urbanos. 
Era como se o movimento de 1844-1848 fosse uma tardia correção da Independência, que não deu uma contrapartida econômica para o povo. No discurso nativista, os brasileiros continuavam preteridos no comércio a retalho, o ramo que mais empregava nos povoados, vilas e cidades. Dentro dos horizontes da economia política popular, a nacionalização do comércio a retalho corrigiria essa falha. Esta reivindicação congregou os grupos subalternos, articulando-os a um partido com representação nacional. O processo alterou a cultura política na província e a vida organizacional das camadas subalternas. Muito antes do movimento abolicionista houve passeatas no Recife, levando petições para as autoridades provinciais. A Insurreição Praieira daria ao Estado a oportunidade de esmagar o movimento dos artistas mecânicos de Pernambuco ainda no seu nascimento. A nacionalização do comércio a retalho continuaria sendo uma reivindicação com forte apelo popular, mas não haveria mais manifestações como aquelas antes do Abolicionismo tomar as ruas do Recife.

Para Joaquim Nabuco, embora fosse o anseio popular, a nacionalização do comércio a retalho era uma proposta reacionária. De fato, ela lembrava os monopólios gremiais do mundo feudal tão desprezados por liberais como Nabuco, que em Minha Formação deixou claro seu entusiasmo com o capitalismo inglês, com a idéia de progresso e da evolução permanente da civilização. Contudo, ensina a História européia que a passagem da Antigüidade para o feudalismo passou pela transição da economia escravista urbana para uma economia gremial corporativista. Para intelectuais educados, certamente era um anacronismo esperar por isso no século XIX. Mas seria esta a visão popular da história?

Não há como saber ao certo como pensavam os artistas mecânicos envolvidos naqueles episódios. Porém a mobilização deles na Praieira e a presença de sua associação à frente de manifestações de rua demonstram que havia uma representação popular, mestiça, abrasileirada, das tradições associativas européias. Os habitantes do Recife não tinham uma bola de cristal para ver que o País caminharia para a modernidade. Dentro do prisma mental em que viviam, acreditavam na necessidade de proteger o trabalhador brasileiro, afinal de contas, na ausência de cativos, os empregadores urbanos nunca esconderam a preferência por imigrantes. A bem da verdade, substituir os cativos em Pernambuco por europeus, sem fazer outros ajustes mais profundos na economia, era uma idéia no mínimo tão utópica quanto a nacionalização do comércio a retalho. Pelos caminhos da cultura popular, que são pouco cartesianos mas não menos reveladores, esta reivindicação denunciava o caráter incompleto da Independência, que trouxe muito pouco para o povo, e ainda oferecia uma solução, privilegiando o trabalhador brasileiro não-escravo, garantido-lhe o emprego. Dentro das perspectivas políticas da época, os traba- 
lhadores livres do Recife pensaram o mais avançado que podiam. Alcançaram o limite da consciência possível. Construíram uma proposta utópica, mas certamente baseada em problemas concretos que as elites locais bem que poderiam, mas nunca quiseram resolver.

\section{NOTAS}

'NABUCO, Joaquim. Um Estadista do Império. Paris: Garnier, 1897, vol. 1, pp. 84, 97, 100, 102. Veja-se ainda o discurso de Borges da Fonseca publicado em 1898, in QUINTAS, Amaro. O Sentido Social da Revolução Praieira. Recife: UFPE, 1977, p. 125. QUINTAS, O Sentido Social, p.38. COSTA PORTO, José da. Os Tempos da Praieira. Recife: Fundação de Cultura da Cidade do Recife, pp. 88, 100.

${ }^{2}$ Embora discordem quanto aos detalhes do processo, MARSON, NARO, CARVALHO e MOSHER concordam neste aspecto. Sobre a constituição do partido praieiro veja-se: QUINTAS, O Sentido Social, pp. 30-32. MARSON, Isabel. O Império do Progresso: A Revolução Praieira. São Paulo: Brasiliense, 1987, p. 209. BARMAN, Roderick. Brazil: The Forging of a Nation, 1798-1852. Stanford, Stanford University Press, 1988, p. 229. MOSHER, Jeffrey C. "Pernambuco and the Construction of the Brazilian Nation-State, 1831-1850". University of Florida at Gainesville, Tese de Ph.D., 1996, cap. 3.

${ }^{3}$ FIGUEIRA DE MELlO, Jerônimo Martiniano. Crônica da Rebelião Praieira: 1848-1849. Recife, 1850; Brasília: Senado Federal, 1978. MELLO REGO, General. A Revolução Praieira. Rio de Janeiro: Imprensa Nacional, 1899. PESSOA DE MELLO, Urbano Sabino. Apreciação da Revolta Praieira em Pernambuco. Rio de Janeiro, 1849; Brasília: Senado Federal, 1978. No Código Criminal de 1830, estes termos indicavam crimes de diferentes graus de gravidade. Dentre eles, a Insurreição era o de maior gravidade. Coleção Brasil Leis, Código Criminal do Império, 1830, capítulos II e IV.

${ }^{4}$ RODRIGUES, José Honório. Conciliação e Reforma no Brasil. Rio de Janeiro: Nova Fronteira 1982, p.111.

${ }^{5}$ MOSHER, p. 12. Sobre as diferenças entre o Partido Liberal e o Conservador, veja-se ainda: NEEDELL, Jeffrey D. "Provincial Origins of the Brazilian State: Rio de Janeiro, the Monarchy, and National Political Organization, 1808-1835”. In Latin American Research Review, vol. 36, n. 3 (2001), pp. 132-151.

${ }^{6} \mathrm{~A}$ narrativa dos combates envolvendo os engenhos encontra-se em: CARNEIRO, Edison. A Insurreição Praieira, 1848-49, Rio de Janeiro: Conquista, 1960. Sobre a Praieira no interior, veja-se ainda CARVALHO, Marcus J. M. de. "A Guerra do Moraes: A Luta dos Senhores de Engenho na Praieira”. Recife: Diss. de Mestrado, UFPE, 1986.

${ }^{7}$ EISENBERG, Peter. Modernizaçäo Sem Mudança. Campinas: Paz e Terra, 1977, p. 172.

${ }^{8}$ Segundo o comandante das Armas que combateu Pedro Ivo, Caetano Alves havia mudado, estava com a cabeça cheia de idéias novas encaixadas à força de martelo pelos senhores 
revolucionários. "Relatórios do comandante das Armas, 1848-1849”. In Revista do Arquivo Público (Recife), 1948, vol. 5, p. 553.

${ }^{9}$ NASCIMENTO, Luís do. História da Imprensa Pernambucana, 1821-1954. Recife: UFPE, 1966, vol. 2, pp. 74-78. Doc. In Autos do Inquérito da Insurreição Praieira, Recife: 1849; Brasília: Senado Federal, 1979, p. 245.

${ }^{10}$ ALMEIDA, Mário M. de. Um Homem contra o Império: Antônio Borges da Fonseca. João Pessoa: União, 1994, capítulo 5. MELLO REGO, p. 23. Veja-se ainda MOSHER, pp. 177-178.

${ }^{11}$ NASCIMENTO, vol. 2, op. cit., p. 62.

${ }^{12}$ QUINTAS, passim. ALMEIDA, op. cit., pp. 269, 270. CHACON, Vamireh. “Introdução”. In Autos, p. LXIII. Sobre a atuação política de Borges da Fonseca no Rio, durante o Primeiro Reinado, veja-se RANGEL RICCI, Maria Lúcia de Souza. A Atuação Política de um Publicista: Antonio Borges da Fonseca. Campinas: Pontifícia Universidade Católica, 1995. RIBEIRO, Gladys Sabina. A Liberdade em Construção. Rio de Janeiro: Relume Dumará, 2002, pp. 267-268.

${ }^{13}$ O Tribuno (Recife), 10/9/1847. Veja-se ainda ALMEIDA, op. cit., p. 143. Sobre o Divino Mestre, veja-se: CARVALHO, Marcus J. M. de. "Que crime é ser cismático? As transgressões de um pastor negro no Recife patriarcal, 1846”. In Estudos Afro-Asiáticos (Rio de Janeiro, Centro de Estudos Afro-Asiáticos), 2000, vol. 36, pp. 97-122.

${ }^{14}$ Department of State: United States Consul in Pernambuco, Microfilm T 344, 6/9/1845.

${ }^{15}$ FIGUEIRA DE MELLO, Crônica, p. 237. Veja-se ainda: MARSON, op. cit., 1987, pp. 8082, 93-94. MOSHER, op. cit., p. 234.

${ }^{16}$ PRADO JR., Caio. Evolução Política do Brasil,. São Paulo: Brasiliense, 1969, pp. 73-77. MARSON, Isabel. Movimento Praieiro, 1842-1849: Imprensa, Ideologia e Poder Político. São Paulo: Moderna, 1980, cap. 1. BARBOSA LIMA SOBRINHO. "A Revolução Praieira”. In Revista do Arquivo Público (Recife), 1948, vol. 5. Veja-se ainda: NARO, Nancy. “The 1848 Praieira Revolt in Brazil”. Chicago: Univ. of Chicago, Diss. de Doutorado, 1980. MARSON, op. cit., 1987. CARVALHO, op. cit., 1986. MOSHER, op. cit., 1996.

${ }^{17}$ Arquivo Público Estadual de Pernambuco, Polícia Civil 327, 9/6/1846; Polícia Civil 17, 23/9/1847; Polícia Civil 18, 11/12/1847. Vide SOARES DE SOUZA, Francisco Belisário. O Sistema Eleitoral no Império. Rio de Janeiro, 1872; Brasília: Senado Federal, 1979, pp. 3435. EISENBERG, op. cit., pp. 203-204. NABUCO, op. cit., 88-89.

${ }^{18}$ Doc. In Autos, pp. 136, 178, 233-234. Código Penal do Império do Brasil com Observações sobre Alguns dos seus Artigos pelo Doutor Manoel Mendes da Cunha Azevedo. Recife, Typographia Comercial de Meira Henriques, 1851, p. 144. Dez anos depois, Borges da Fonseca ainda reivindicava a anistia para as vítimas do recrutamento. Almeida, p. 281.

${ }^{19}$ Doc. in Autos, p. 306. Sobre os proprietários dos engenhos em tela vide MELLO REGO, op. cit., pp. 206-208. “Relatórios do comandante das Armas, 1848-1849”. In Revista do Arquivo Público (Recife), 1948, vol. 5, p. 619. FIGUEIRA DE MELLO, Crônica, op. cit., pp. 95, 145.

20"Relatórios do Comandante das Armas, 1848-1849", p. 525. Doc. In Autos, p. 162. 
${ }^{21}$ Arquivo Público Estadual de Pernambuco, Correspondência Reservada, R 18-5, 5/1/1849. “Relatórios do Comandante das Armas, 1848-1849”, p. 309.

${ }^{22}$ Doc. In Autos, pp. 130-131, 182, 197, 254. FIGUEIRA DE MELLO. Crônica, op. cit., pp. $141,251$.

${ }^{23}$ Doc. In Autos, pp. 398-400, 401-403, 411-424.

${ }^{24}$ O Capibaribe (Recife), 10/7/1848.O Tribuno (Recife), 5/10/1847.

${ }^{25} \mathrm{Na}$ raiz do vintismo lusitano estavam os alicerces de uma noção liberal do que seria o povo, tomado então como um pressuposto para a própria existência do rei. Com ajustes conjunturais, esta noção seria instrumental para os liberais brasileiros em diversos momentos da história imperial. Sobre a construção e emprego deste conceito em Portugal antes da Independência, veja-se CARVALHO SOUZA, Iara Lis. Pátria Coroada: O Brasil como Corpo Autônomo, 1780-1831. São Paulo: UNESP, 1998, pp. 74-77.

${ }^{26}$ Doc. In Autos, pp. 54, 306. Figueira de Mello, Crônica, op. cit., p. 95.

${ }^{27}$ Veja-se: BEATTIE, Peter. The Tribute of Blood: Army, Honor, Race and Nation in Brazil, 1864-1945. Durnham e Londres: Duke University Press, 2002.

${ }^{28}$ Doc. In Autos, pp. 71, 154, 183, 213, 277, 285, 289, 295, 300, 303, 388, 399. FIGUEIRA DE MELLO. Crônica, op. cit., p. 97.

${ }^{29}$ Doc. In Autos, pp. 274, 279, 203, 281, 287-289, 294, 298-301, 303, 389. FIGUEIRA DE MELLO. Crônica, op. cit., p. 191-192.

${ }^{30}$ Doc. In Autos, pp. 269, 279, 285.

${ }^{31}$ Idem, pp. 281, 300.

${ }^{32} I d e m$, pp. 54, 288, 298, 299, 301. FIGUEIRA DE MELLO. Crônica, op. cit., p. 192. PESSOA DE MELLO, op. cit., p. 233. Em 1844, Manoel Joaquim da Costa foi candidato a eleitor apoiado por Borges da Fonseca. O Nazareno (Nazaré-PE), 6/9/1844, apud CAVALCANTI JR., Manoel Nunes. "Praieiros, Guabirus e 'Populaça': As Eleições Gerais de 1844 no Recife”. Recife, Dissertação de Mestrado, UFPE, 2001, anexo IX. Diário de Pernambuco (Recife), 6/11/47. CARVALHO, op. cit., 2000, pp. 98, 113.

${ }^{33}$ Autos, p. 52. Agradeço a Flávio Gomes e Isadora Mota por confirmarem esta cifra no microfilme dos originais dos Autos na Biblioteca Nacional no Rio de Janeiro.

${ }^{34}$ CASTRO, Jeanne Berrance. A Milícia Cidada: A Guarda nacional de 1831 a 1850. São Paulo: Editora Nacional, 1979, p. 49. Arquivo Público Estadual de Pernambuco, Comando das Armas, vol. 11, 9/4/1848; Tesouraria Provincial, vol. 7, 13/5/1842. Revista do Arquivo Público (Recife), 1848, vol. 5, p. 588. FIGUERIA DE MELLO. Op. cit., p. 156. CARNEIRO. Op. cit., p. 21. FREIRE E. A. L. Op. cit., e MELLO, M.M. P. “Artesãos Alemães no Recife”. In Cadernos de Estudos Regionais, UFPB, 1976, vol. 1, p. 56. Arquivo Público Estadual de Pernambuco.

${ }^{35}$ MOSHER, op. cit., pp. 147-148. QUINTAS, O Sentido Social, op. cit., p. 93. Sobre as eleições de 1844 em Pernambuco, veja-se: CAVALCANTI JR. Op. cit., 2001.

${ }^{36}$ Torre do Tombo, Lisboa: Coleção do Ministério dos Negócios Estrangeiros, Pernambuco, Caixa 3, 12/7/1848. 
${ }^{37}$ É atribuída a Borges da Fonseca a produção de um abaixo-assinado com cinco mil assinaturas em favor da nacionalização do comércio a retalho. Teria sido esta a origem do nome dos Cinco Mil (ALMEIDA, p. 132). É possível que isso tenha acontecido. Mas de acordo com os jornais, as passeatas contaram com a presença de duas mil pessoas. Como quase tudo na vida de Borges era hiperbólico, preferimos esta avaliação mais modesta.

${ }^{38}$ Arquivo Público Estadual (Recife): "Relação Numérica da População Livre e Escrava do Primeiro Distrito do Termo do Recife", 10/1/1856. FIGUEIRA DE MELLO, Jerônimo Martiniano. Ensaio sobre a Estatística Civil e Política de Pernambuco. Recife, 1852; Reedição: Recife, Conselho Estadual de Cultura, 1979, p. 193.

${ }^{39}$ No atual município do Recife, com um milhão e trezentos mil habitantes, mesmo abstraindo metade da população entre velhos, crianças, etc., seria preciso reunir uma massa de pelo 85 mil pessoas para fazer uma manifestação equivalente. Tomando como referencial não o minúsculo município, mas o grande Recife com mais de três milhões de pessoas, a passeata lotaria um Maracanã.

${ }^{40}$ Torre do Tombo (Lisboa): Ministério dos Negócios Estrangeiros, Pernambuco, Caixa 3, 25/11/1844, 10/3/1845, 23/9/1845, 9/2/1846.

${ }^{41}$ Mesmo na pátria-mãe do movimento operário moderno, a Inglaterra, lembra Dick Geary, que por volta de 1850, os sindicatos de trabalhadores especializados visavam a proteger seus associados tanto dos patrões, como de outros trabalhadores concorrentes. GEARY, Dick. ”The Working Classes". In STEARNS, Peter (Ed.) Ecyclopedia of European Social History. Nova York: Scribner, 2001, vol. 3, pp. 121-138.

${ }^{42}$ ABREU CASTRO, Bernadino Freyre de. Nossa Senhora dos Guararapes. Recife: 1847; Recife: Fundação da Cidade do Recife, 1980. Torre do Tombo, Lisboa: Coleção do Ministério dos Negócios Estrangeiros, Pernambuco, Caixa 3, 7/4/1849, 15/10/1850. Veja-se ainda: SILVA, Raul José Candeias da. Subsídios para a História da Colonização do Distrito de Moçâmedes Durante o Século XIX. Lisboa: Centro de Estudos Históricos Ultramarinos, 1973, pp. 20, 26. Naro, p. 70.

${ }^{43}$ Arquivo Público Estadual de Pernambuco, Polícia Civil, vol. 328, 10/12/1847.

${ }^{44}$ LINDHOLM, Charles “Liderança”. In William Outhwaite e Tom Bottomore, Dicionário do Pensamento Social do Século XX. São Paulo: Zahar, 1993, pp. 426-428.

${ }^{45}$ CHARTIER, Roger, The Cultural Origins of the French Revolution. Durham and London, 1995, pp. 27-30.

${ }^{46}$ NABUCO, op. cit., 91. Docs. In Autos, pp. 235, 237, 241.

Artigo recebido em 1/2003. Aprovado em 4/2003. 